\title{
Effect of Firms' Characteristics on Timeliness of Financial Reports of Quoted Insurance Companies in Nigeria
}

\author{
Adediran, Samson Adewale Adejoh,,Edogbanya Oyewole, Olubukola Sarah \\ Department of Accounting, Kogi State University, Anyigba, Kogi State, Nigeria
}

\begin{abstract}
Financial information needs to be made available to users as rapidly as possible to make corporate financial statement information relevant for decision making process. Timely reporting on financial statements is necessary for healthy financial markets. Against this backdrop, this study investigates the effect of firm characteristics on timeliness of financial reports on Nigerian insurance companies from 2008-2017. The study adopts ex-post facto research design and the data were sourced from the financial statements of the sampled companies. The dependent variable was measured by audit report delay while the independent variable was proxied by board size, firm leverage ratio and firm size. The analysis was conducted with the aid of STATA 12 software. The data were analysed by Pairwise correlation, descriptive statistics and ordinary least square (OLS) multiple regression technique. The result reveals that board size has a significant negative effect on audit report delay while firm size has a significant negative effect on audit report delay. The result further reveals that firm leverage has an insignificant negative effect on audit report delay. The study recommends among other things that management of large companies should always ensure that highly qualified personnel are placed at the final accounts section of the parent company and that compilation of financial reports should be gradual and not only towards the accounting year end to avoid unnecessary delay in publication of financial statements.
\end{abstract}

Keywords: Timelines, Financial report, firm size and firm leverage

DOI: $10.7176 /$ RJFA/10-24-06

Publication date: December $31^{\text {st }} 2019$

\section{Introduction}

One pertinent characteristic of sound financial report is that the information that it holds need to be release in a timely manner. Financial accounting standards board (FASB 2010) emphasizes timeliness as one of the key components of decision-driven informational relevance. Accordingly, if information is not available as at when due, but, rather made available so late that it bears no value for future action, then it is operationally irrelevant. The quality and usefulness of information will be jeopardized if financial information is not provided on time. Investors, accounting professionals, board of directors and regulators have considered timeliness of accounting information as an important feature of financial reporting quality (Ahmed \& Che-Ahmad, 2016). Turel (2010) notes that the provision of unverified financial accounting statements and associated information automatically negates the essence of timely information and so there is great pressure on the external auditor to complete the audit and issue the audit report without undue delay.

Timeliness of corporate financial report refers to the promptness it takes a company from the date the accounting year ends to the date the report is published, and it is one of the qualitative characteristics of financial reporting which determines the relevance of the information in the financial reports. Emeh and Appah (2013) assert that financial information has to be made available in a timely manner so that the users can have access to it whenever they are in a position to make decision and avoid insider trading. A financial report is said to be timely if the information is presented to the users as ready to use before the information loses its meaning and while it still has the capacity to be used in taking a decision

The Securities and Exchange Commission (SEC) which is the regulatory agency of Nigeria stock market sets March 31 for every listed firm to submit its audited financial reports ended on December 31 in the previous year. Other Nigerian regulators such as the Investment and Security Act and Insurance Act require a financial statement to be made available on or before 90 and 180 days respectively (Iyoha, 2012). Ibadin and Afensimi (2015) point out that Section 347 of the Companies and Allied Matters Act of 2004 as amended, grants an additional 14 days period of grace to companies (in addition to the 90 and 120 days) for their financial statements to be delayed, in recognition of the pressures that might be associated with the complexity of work during the accounting year end of companies. This, they added is in recognition of the need for more disclosures as required by IFRS which may affect the timing of financial statement presentations. Bakare, Taofik and Jimoh (2018) opine that in ensuring timeliness of financial reports, attention must to be accorded the issue of accuracy so that accuracy is not sacrificed for timeliness. They added that a firm might be timely in releasing its annual financial reports but may deliberately skip the essential information in such reports, and as such, the goal for enforcing timely reports is defeated.

This study is motivated by the desire to conduct an independent study to find out the influence of firm characteristics such as the size of the firm, number of members on the board and the debt to equity ratio have on 
the timeliness of financial reports of quoted insurance companies in Nigeria.

\section{Objectives of the Study}

The main objective of this study is to investigate effect of firm characteristics on timeliness of financial reports in Nigerian quoted insurance companies, while the specific objectives are to:

i) evaluate the effect of board size (BRDSZE) on audit report delay (ARDLY) of Nigerian quoted insurance companies;

ii) determine the effect of firm leverage ratio (FLVRG) on audit report delay of Nigerian quoted insurance companies; and

iii) examine the effect of firm size (FSZE) on audit report delay of Nigerian quoted insurance companies.

\section{Scope of the Study}

This study shall cover a ten year period from 2008-2017 and will focus on the relationship between five characteristics of firms namely: firm size, board size and firm leverage and audit report delay of the 15 insurance companies quoted on the Nigeria stock exchange.

\section{Review of related literature}

\subsection{Conceptual Framework of the Study}

The conceptual framework of the study is made up of board size, firm size, and firm leverage ratio representing firm characteristics and audit report delay which measures financial reports timeliness.

\subsection{Firm characteristics}

Firm characteristics may be defined as those attributes that are directly related to the company which Kogan and Tian (2012) listed to include ownership structure, board characteristics, age of the firm, dividend pay-out, profitability, leverage, liquidity, committee size, board size, board composition and access to capital markets and growth opportunities among others. Zou and Stan (1998) describe firm characteristics as a firm's demographic and managerial variables which in turn comprise part of the firm's internal environment include firm size, leverage, liquidity, sales growth, asset growth, and turnover. Firm characteristics may also be defined as attributes which are specific or peculiar to a firm and therefore are independent of other firms.

\subsection{Timeliness of Financial reports}

Financial reports timeliness generally refers to the length of time from a company's financial year-end to the date of the auditor's report and thus it is measured as the number of days between a firm's fiscal year-end and the report date (Ibadin \& Afensimi, 2015). Timeliness of financial report is the ability of a company to make public its financial statement after the end of accounting year within the stipulated period in Nigeria. Arowoshegbe, Uniamikogbo and Adeusi (2017) define timeliness as the capacity of the decision makers to access information before losing its relevance and ability to effects judgments. A company's failure to make public its reports within the period allowed by law is referred to as audit delay or audit report lag which considers the number of days after the end of accounting to the day the report is published. This study shall be using these terms interchangeably.

Audit delay can be explained as the duration of the completion of the audit, which is from the date of closing the book to the date the audit report is published (Utami, 2006). Al-Tahat (2015) states that, timeliness can be measured as the time between when data is expected and when it is readily available for use. The International Accounting Standard Board (2008) defines timeliness as making the financial information available to users on time so as to influence their decision. Ahmad and Kamarudin (2003) define audit report lag as the number of days between the date of the financial report and the date of the audit report.

\subsection{Board Size and timeliness of financial reports}

Board size can be defined as the total number of the members of a firm's board of directors (BOD), it an important corporate characteristic that significant influence the timeliness of financial reports. Board of directors has the responsibility for monitoring, communication, participation and coordination, all of has direct bearing on how timely the financial report can be made public after the end of the accounting year. Zailut (2010) states that, if one or more of these responsibilities becomes a problem as a result of the large number of members of the board it can affect the timeliness of financial reporting. Ahmed and Che-Ahmad (2016) noted that board size has been shown to be a significant part of the ability of boards to effectively monitor management and to work efficiently together to oversee the running of the firm so as to a timely release of the financial statement after the financial year end.

Baatwah, Zalailah and Ahmad (2016) assert that larger board members are more helpful to the companies in terms of sharing knowledge, experience, and ideas which make them more efficient in terms of prompt decision 
making and therefore will not condone delay in financial reports. $\mathrm{Wu}, \mathrm{C}-\mathrm{H}, \mathrm{Wu}, \mathrm{C}$. and Liu (2008) argue that a large board will not delay its financial reports since there are no weaknesses in the coordination of the board.

\subsection{Firm leverage ratio}

Leverage also refers to as gearing is can be described as the component of companyls capital that is financed through debts. A firm is described as leveraged when it is financed partly by long term debts. Thus, leverage measures the extent of the borrowed finance resources used in a firm (Alkhatib \& Marji, 2012). A high leverage firm is expected to release its annual report faster than a low leverage firm, due to the high monitoring cost associated with a highly leveraged firm. Debt holders always include clauses in their debt contracts, one of which require prompt and frequent disclosure (Owusu-Ansah, 2000). Abdulla (1996) is of the view that the higher the amount of a debt utilised to finance the operation of a firm, the more pressure is on the firm to provide a financial audit statement as at when due.

\subsection{Firm size and timeliness of financial reports}

Megayanti and Budiartha (2016) explains that company size negatively affects audit report lag adding that companies that have gone public or large companies have good internal control systems, which can reduce the number of errors in financial reports, thereby, making it easier for the auditor to audit the financial reports. Arowoshegbe, Uniamikogbo and Adeusi (2017) also confirmed that company size significantly affects audit report lag, concluding that the bigger the company size, the shorter the delays in the auditing process. Khasharmeh and Aljifri (2010) pointed out that, larger companies may have stronger internal controls, which in turn should reduce the propensity for financial statement errors to occur and enable auditors to perform more interim work. They added that larger companies may be able to exert greater pressures on the auditor to start and complete the audit in a timely manner. Owusu-Ansah (2000) argues that large firms have accounting staff and sophisticated accounting information systems that result in more timely annual reports.

\subsection{Theoretical Review}

There are several theories that have been used by different scholars to underpin studies on timeliness but the adopted theory for this study is. Agency theory: This theory was developed by (Jensen and Meckling, (1976). This study is anchored on the agency theory which is based on the relationship between the principal (owners) and the agent (Managers), because, the issue of timeliness of financial reports is a matter almost exclusively in the purview of the management. Principal can therefore monitor his agent by involving a third party to check their books. The theory assumes that in the presence of information asymmetry, the agent is likely to pursue interest that may conflict with that of the principal. Since managers are said to favour perks of office and power even at the expense of shareholders' interest, they are likely to pursue interests that may hurt their principals (the shareholders). The theory therefore suggests an optimal debt level that would arise as a result of agency cost. The theorists suggested a situation whereby the interest of the managers in the firm should increase in order to be aligning with the owners. The debt level should also be used to motivated or control managers' tendency for extra consumption. The theory also assumes that free cash flow in a firm can be controlled by increasing the managers' stake in the firms or debt in the capital structure thereby reducing the amount of free cash available to managers. Singh and Davidson (2003) argue that when management provides inaccurate financial reporting information, it introduces earnings management as a type of agency cost. In order to avoid conflict of interest, the principal can establish monitoring system including financial statement audit which will help to reduce information asymmetry and protect the interest of the principal and all shareholders by providing assurance that financial statement prepared by management reflects the 'true' economic condition and operating results of the entity.

\subsection{Empirical Review}

Mutiara, Zakaria and Anggraini (2018) reveal the effect of each of company size, company profit, solvency and the size of public accountant on audit report lag for the infrastructure, utility and transportation sectors listed on the Indonesian Stock Exchange. The population of the study are infrastructure, utility and transportation companies that are listed on and supervised officially by the Indonesian Stock Exchange from 2013-2015. The technique used for choosing the sample was purposive sampling. The sample consisted of 57 companies chosen from the population. The data was analysed using double regression analysis. The study finds that company size has a negative and significant effect on audit report lag and that company profit has a negative and significant effect on audit report lag. They recommended for further researches that should study companies that works in field other than infrastructure, utilities and transportation, mining or banking.

Bakare, Taofiq and Jimoh (2018) examine the effect of board characteristics on timeliness of financial reporting of listed insurance firms in Nigeria for the period 2011-2016 The study used correlational research design. The source of data which were collected from the published annual financial reports of studied listed 
insurance firms in Nigeria. The sample size was fifteen (15) listed insurance firms in Nigeria. The data collected were analyzed with the aid of GLS multiple regression technique. Using 90 firm-year paneled observations, the result of the random effect showed that board size has a positive and significant effect on the timeliness of financial reporting of listed insurance firms in Nigeria. They recommended that the shareholders of listed insurance firms should ensure that the board has a reasonable large amount of members as it has been revealed that a larger board will reduce the delay of releasing the financial reports.

Hoang, Dang and Nguyen (2018) study the factors affecting the timeliness of financial reports (FR) of enterprises in Vietnam. They used panel data with 1070 observations, at 214 companies listed on Vietnam's stock market in the period 2012 - 2016. Retrieved results using the GLS method shows that there are 04 independent variables, including consolidated financial reports (CON), the audit firm (AUDIT), profitability (ROA) and the size of the business (SIZE) with relation to the timeliness of financial reports and statistical significance. There are two factors, including financial leverage (LV) and industry (INDUSTRY) which do not affect the timeliness of financial reports. In addition, the research results show that there are differences and statistical meanings in the publishing time of different types and starting times of financial reports. Based on these results, they recommended a boost in the timeliness of financial reports.

Warrad (2018) seeks to discuss the extent of association between corporate governance characteristics and the audit report lag ARLAG for the listed Jordanian Banks during the period from 2014 to 2016. The study used statistics measurements and tools to clarify the relations and hypotheses. The results found a significant relation between the corporate governance characteristics and audit report lag ARLAG jointly and separately with the board size BORSIZE, board diligence BORDEL, audit committee size ACSIZE and audit committee diligence ACDEL, and the relation was controlled by two variables: return on equity ROE and company size COMSIZE. It was recommended that other researches should be conducted on other sectors to reveal the impact on the timing of the auditors' reports.

Ibadin and Afensimi (2015) examine the determinants of audit report lag in the Nigerian context. Specifically, the study examined the effects of the following factors on Audit fees; Audit firm type, Leverage, Return on equity, Firm size, subsidiaries and Year-end. The panel research design was used for the study. The data was sourced from the annual reports of all financial companies quoted on the floor of the Nigerian stock exchange. The method of data analysis utilized in the study is the panel data estimation techniques (pooled, fixed and random effects regression). In line with the study objectives, the finding reveals that Company size has no significant positive impact on audit delay; Firm's financial performance has a significant impact on Audit delay; Leverage has no significant impact on Audit delay;. They recommended that in achieving the objective of making the financial statements readily available for timely decisions, the regulatory bodies should put in place measures to ensure strict compliance with 3 months window for financial reports preparation and presentation.

\section{Methodology}

This study adopts the ex-post facto research design because the firms" activities under study have taken place and the historical data documented in the secondary form by the various insurance companies in their annual reports. The sample size of the study is 15 out of the 28 insurance companies in Nigeria. 12 not quoted and 1 quoted but has no useful information for the study were filtered out. The data were analysed using Pairwise correlation, descriptive statistics and Ordinary Least Square (OLS) multiple regression technique OLS was selected for testing the hypotheses because of its best linear unbiased estimation (BLUE) properties on linear variables. STATA 12 software is used for analysis.

\subsection{Model Specification}

The dependent variable is Timeliness of financial reports proxied by audit report delay (ARDLY) while the independent variable firm characteristics is represented by board size (BDSZE), firm size (FSZE) and firm leverage rate (FLVRG). Specifically, the functional linear regression as used by Alsmady (2018) $[$ TFRit $=$ CEODit + SIZEit + AGEit + BODOWit + BODDit + NEDit + ćit......1] is presented as follows:

$\mathrm{ARDLY}=f(\mathrm{BRDSZE}+\mathrm{FSZE}+\mathrm{FLVRG}$

Econometrically, the above equation is rewritten as:

ARDLYit $=\beta 0+\beta_{1}$ BDSZEit $+\beta 2$ FLVRGit $+\beta_{3}$ FSZEit $+\mu$ it

(2) $[$ Model]

Where:

ARDLY $=$ an indicator representing audit report delay (proxy for dependent Variable);

$\beta 0=$ Intercept term (a constant);

$\beta 1-\beta 3=$ Coefficients of the proxies of independent variables (firm characteristics)

BDSZE $=$ a predictor representing Independent Variable (board size);

FLVRG $=$ a predictor representing Independent Variable (firm leverage);

FSZE $=$ a predictor representing Independent Variable (firm size);

$\mu \mathrm{t}=$ Stochastic error term; 
it $=$ Timed panel data; and

$f=$ Functional relationship

\subsection{Data Presentation and Analysis}

Appendix A shows figures representing audit report delay (ARDLY), board size (BRDSZE), firm leverage ratio (FLVRG) and firm size (FSZE).

Correlation Test for Multicollinearity

Table 1 below shows the result of the Pairwise correlation test for the presence of multicollinearity problem among the proxies for the variables.

\section{Correlation}

\begin{tabular}{|c|c|c|c|c|}
\hline | & 1_ARDLY & BRDSZE & & FLVRG \\
\hline L_ARDLY & 1.0000 & & & \\
\hline BRDSZE & 0.0764 & 1.0000 & & \\
\hline FLVG & 0.0238 & -0.0100 & 1.0000 & \\
\hline L FSZE & 0.5566 & 0.3632 & 0.0078 & 1.0000 \\
\hline
\end{tabular}

Source: Researcher' computation, 2019

Table 1 above shows that there is no problem of multicollinearity among the proxies of the independent variables as there is no correlation between them that is higher than 0.85 (or $85 \%$ ) which is the maximum, if exceeded, meant that multicollinearity problem exist according to Hair, Tathan and Anderson, (2005). The absence of the multicollinearity problem meant no further diagnostic investigation is necessary on the data.

\subsection{Descriptive Statistics}

Table 2 below shows the descriptive statistics of the overall data set comprising of the proxies for the variables.

\begin{tabular}{|c|c|c|c|c|c|c|c|}
\hline Variable & Obs & Mean & Std. Dev. & Min & Max & Skewness & Kurtosis \\
\hline & 150 & 0.8400929 & 0.0306415 & 0.5580453 & 0.889924 & -6.0361 & 53.1162 \\
\hline$\overline{\text { brdsze }}$ & 150 & 10.37333 & 2.568646 & 6 & 17 & 0.7999 & 2.9527 \\
\hline flvg | & 150 & 14.14792 & 160.6451 & -6.737542 & 1968.213 & 12.1188 & 147.9128 \\
\hline log_fsze $\mid$ & 150 & 6.934667 & 0.4073629 & 3.61 & 7.76 & -4.4251 & 35.3225 \\
\hline
\end{tabular}

Table 2 above shows that all the variables have means that fall between their minimum and maximum respectively which signifies that the series are evenly spread. Furthermore, the Table shows the standard deviation which highlights the extent of dispersion of the series to be lower than their respective mean except for firm leverage. What this means is that, all the variables except firm leverage have had a slow growth during the period studied, while firm leverage had a faster growth rate.

\subsection{Normality Tests}

This normality test adopted for this study is skewness normality test Skewness normality test determine whether a series is asymmetrically (normally) or asymmetrically distributed around expected mean of 0 . From Table 3.3 above, skewness statistics for BRDSZE and FLVRG are positive figures (right leg; > 0), while ARDLY and FZSE) have negative values (left leg; $<0$ ). This combined features of negative and positive figure indicates that the series is normally distributed. 


\subsection{Regression Analysis}

Table 3 below shows the result of the regression analysis conducted by the aid of Ordinary Least Square technique.

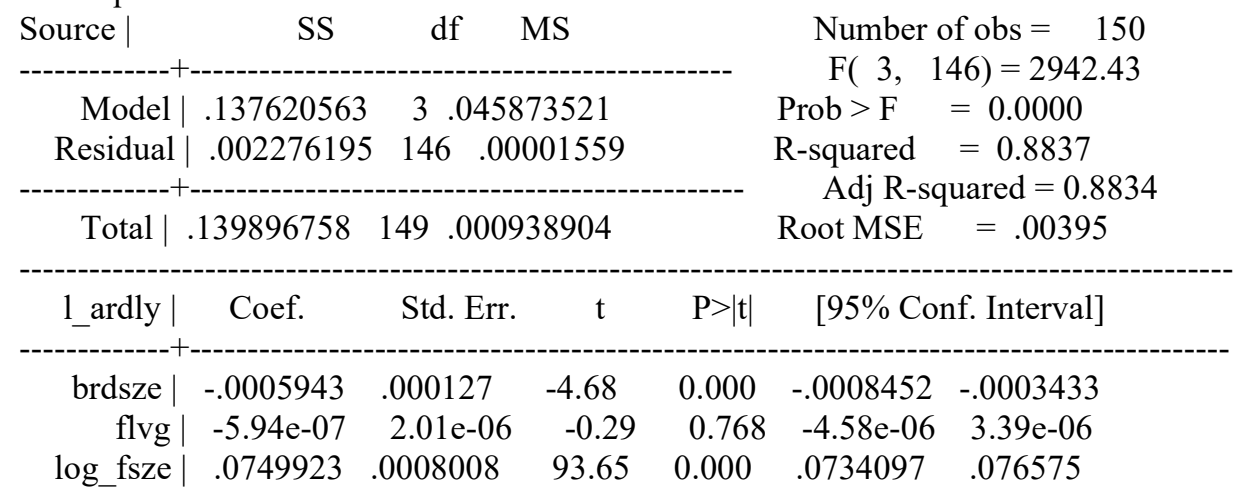

Table 3 above shows that the coefficient of determination adjusted for the degree of freedom (Adjusted RSquare) is 0.8834 or $88 \%$, meaning that the proxies representing the independent variable (firm characteristics) are jointly accountable for about $88 \%$ variation in the dependent variable during the 10 years of this study. The table also shows F-statistics of 2942.43 and F-prob value of 0.0000 ( $1 \%$ significance level) which indicates that the data fit into the model well and that result obtained is good to be relied upon for decision making.

Table 3 also reveals that audit board size (BRDSZ) has a significant negative effect on timeliness of financial reports represented by audit report lag and that holding all other variables constant, an additional member added to the board will reduce audit report delay. The result above indicated that firm leverage (FLVRG) has an insignificant but negative effect on timeliness of audit report such that a rise in the leverage ratio will lead to a reduction in the days of publishing the audit reports. Finally, the regression analysis shows that firm size (FSZE) has a significant positive effect on timeliness of financial reports and that an increase the total assets (which measures firm size in this study) will be lead to the financial reports taking more time to be published.

\subsection{Test of Hypotheses}

The result from Table 3 above reveals that board size (BRDSZE) has a coefficient of -0.0006 , a t-stat of -4.68 and a prob of 0.000 indicating that board size has a significant effect on audit report delay. This result implies that the null hypothesis One (Hol) which states that board size has no significant effect on audit report delay is rejected.

The result in Table 3 also reveals that firm leverage ratio (FLVRG) has a coefficient of -5.94, a t-stat of 0.29 and a prob of 0.768 , this means that firm leverage rate has an insignificant negative effect on delay in financial reporting and that the null hypothesis Two (Ho2) which states that firm leverage has no significant effect on audit report delay is accepted.

Finally, Table 3 above shows that firm size (FSZE) has a coefficient of 0.0750 , a t-stat of 93.65 and a prob of 0.000 indicating that firm size represented by the natural logarithm of total assets has a significant positive effect on audit report delay. This result shows that the null hypothesis Three (Ho3) which states that firm size has no significant effect on audit report delay is rejected.

\subsection{Discussion of the Findings}

The finding of this study shows that board size has a significant negative effect on audit report delay among insurance firms such that an increase in the number of people on the board of a company, the earlier will the audit report be published. This finding is in agreement with those of Ahmad, Yunos and Yunos (2018); Bakare et al (2018); and Rahmawati (2018) who also found out that board size has a significant effect on timeliness of financial reports represented in this study by audit report delay. The finding, however, disagrees with those of Al-Tahat (2015); Ekienabor and Oluwole (2018); and Mutiara (2018) whose reports indicated that board size has an insignificant effect on timeliness of financial reports.

The finding of this study also reveals that firm leverage (FLVRG) has an insignificant negative effect on audit report lag of insurance firms in Nigeria and that an increase in the debt to equity ratio (leverage) of the firms will reduce audit reports delay a little. This finding is supported by those of Al-Tahat (2015) who also found out that firm leverage has an insignificant effect on timeliness of financial reports. The finding, however, did not agree with those of Alkhatib and Marji (2012); Sakka and Jarboui (2016); and Susandya, Yuliastuti and Putra (2018) whose findings indicated that firm leverage has a significant effect on timeliness of financial reports.

The study further found out that firm size has a significant positive effect on audit report delay among insurance firms in Nigeria such that an increase in the size of a firm measured in this study by the natural logarithm of total assets, the longer will the audit report take to be published. This finding is in tandem with 
those of Sakka and Jarboui (2016); Arowosegbe et al (2017); and Rahmawati (2018) who also reported that firm size has a significant effect on timeliness of financial reports. The finding, however, does not tally with those of Alkhatib and Marji (2012); Ibadin and Afensimi (2015); Mutiara, et al (2018) whose reports indicated an insignificant effect of firm size on timeliness of financial reports.

\section{Conclusion}

From the result of this study, it can be concluded that board size which is the number of members on the board of directors of companies has shown to be a serious determinant of early publication of financial reports of insurance companies quoted in Nigeria. Companies must ensure the size of the board is kept above the minimum and members with accounting and financial expertise must for a substantial proportion of the board. Finally, from this study, increase in firm size will adversely affect early publication of financial report as a result of the volume of paper work to be done due largely to existence of subsidiaries, branches and units among others that need to be harmonized. Management must therefore ensure a well-coordinated internal control and engagement of qualified finance personnel receive priority to ease pressure when putting financial reports together.

\subsection{Recommendations}

Based on our findings and conclusion of this study, the following recommendations are made.

i) Insurance companies should ensure that persons with expert knowledge of accounting and finance constitute a substantial part of the board of directors and that when any of such members retire or leave the services of the company, they should be replaced with persons with similar qualities.

ii) Management of insurance companies should enter into debt financing strictly only for profitable investment purposes, so that borrowed money can generate returns that can offset the resulting liability. The resultant good news would propel them to release financial reports much earlier than what is obtainable now.

iii) Firm size expectedly results in delay in the financial reporting process due largely the volume of work to be done. Management of large companies should always ensure that highly qualified personnel are placed at the final accounts section of the parent company and that compilation of financial reports should be gradual and no only toward the accounting year end to avoid unnecessary delay experienced during the period of this study.

\section{References}

Abdulla, J. Y. A. (1996). The timeliness of Bahraini annual reports. Advances in International Accounting, 9(1), 73-88.

Ahmad, A. R., \& Kamarudin, K. A. (2003). Audit delay and the timeliness of corporate reporting: Malaysian evidence. Available @ https://www.researchgate.net/publication/242086429

Ahmad, S. A., Yunos, S. F. M., \& Yunos, R. M. (2018). Timeliness of financial reporting in the Shariahcompliant companies: Effects of audit committee's and firms' characteristics. Insight Journal, 1(1), 49-59.

Ahmed, M. I., \& Che-Ahmad, A. (2016). Effects of corporate governance characteristics on audit report lags. International Journal of Economics and Financial Issues, 6(1), 159-164.

Alkhatib, A., \& Marji, Q. (2012). Audit reports timeliness: Empirical evidence from Jordan. Procedia - Social and Behavioral Sciences 62(1), 1342-1349. Available at www.sciencedirect.com.

AL-Tahat, S. S. Y. (2015). Company attributes and the timeliness of interim financial reporting in Jordan. International Journal of Application or Innovation in Engineering \& Management, 4(3), 6-16.

Arowoshegbe, A. O., Uniamikogbo, E., \& Adeusi, A. S. (2017). Factors affecting timeliness of an audit report in Nigeria. Funai Journal of Accounting, Business and finance, 1(1), 26-38.

Baatwah, S, R., Zalailah, S., \& Ahmad, N. (2016). Audit committee financial expertise and financial reporting timeliness in emerging market: Does audit committee chair matter? Available at: https://www.researchgate.net/publication/319260869.

Bakare, O. U., Taofiq, A.,\& Jimoh, J. A. (2018). Effect of board characteristics on timeliness of financial reporting of listed insurance firms in Nigeria. Online Journal of Arts, Management and Social Sciences (OJAMSS), 3(1), $126-136$

Ekienabor, E., \& Oluwole, O. S. (2018). Reliability of timeliness in financial reporting in Nigeria. International Journal of Research Publications, 1(1), 1-15. Available at: www.ijrp.org.

Emeh, Y., \& Appah, E. (2013). Audit committee and timeliness of financial reports. Journal of Economics and Sustainable Development, 4(20), 14-25.

Financial Accounting Standards Board (FASB) (2010). Conceptual framework project updated as of 1 February 2009. Retrieved 02 July, 2010 from http://www.fasb.org/index.shtml.

Hair, J. F., Tathan, R. I., \& Anderson, R. E. (2005). Multivariate data analysis. (6 ${ }^{\text {th }}$ ed.) Printice Hall.

Hoang, T. V. H., Dang, N. H., \& Nguyen, T. T. P. (2018). The study of factors affecting the timeliness of financial reports: The experiments on listed companies in Vietnam. Asian Economic and Financial Review, 8(2), 294-307. DOI: 10.18488/journal.aefr.2018.82.294.307. 
Ibadin, L, A., \& Afensimi, E. (2015). Corporate attributes and audit delay in emerging markets: empirical evidence from Nigeria. International Journal of Business and Social Research, 5(3), 1-10.

Iyoha, F. O. (2012).Company attributes and the timeliness of financial reporting in Nigeria. Business Intelligence Journal, 5(1), 41-49.

Khasharmeh, H. A., \& Aljifri, K. (2010). The timeliness of annual reports in Bahrain and the United Arab Emirates: An empirical comparative study. The International Journal of Business and Finance Research, 4(1), 51-71.

Kogan, L., \& Tian, M. (2012). Firm characteristics and empirical factor models: A data-mining experiment. International Finance Discussion papers, 1070.

Megayanti, H., \& Budiartha. A (2016). The influence of auditor substitution, company size, profit and loss on audit report lag. Journal of Accounting, Udayana University, 14(2), 1481-1509.

Mutiara, Y. T., Zakaria, A., \& Anggraini, R. (2018). The influence of company size, company profit, solvency and firm size on audit report lag. Journal of Economics, Finance and Accounting, 5(1), 1-10. DOI: 10.17261/Pressacademia.2018.779.

Owusu-Ansah, S. (2000), Timeliness of corporate financial reporting in emerging capital markets: Empirical Evidence from the Zimbabwe Stock Exchange. Accounting and Business Research, 30(3), 241-254.

Rahmawati, E. (2018). Information content and determinants of timeliness financial reporting: Evidence from an emerging market. Academy of Accounting and Financial Studies Journal, 22(4), 1-15.

Sakka, I. F., \& Jarboui, A. (2016). Audit reports timeliness: Empirical evidence from Tunisia. Cogent Business \& Management, 3(1), 1-13. Available at: http://dx.doi.org/10.1080/23311975.2016.1195680.

Susandya, A. A. P. G. B. A., Yuliastuti, I. A. N., \& Putra, G. B. B. (2018). the effect of cooperative's characteristic on financial reporting timeliness. International Journal of Dynamic Economics and Business 2(4), 269-292. DOI: https://doi.org/10.29259/sijdeb.v2i4.269-292.

Turel, A. (2010). Timeliness of financial reporting in emerging capital markets: Evidence from Turkey. Istanbul University Journal of the School of Business Administration, 39(2), 227-240. Available @ www.ifdergisi.org.

Utami, W. (2006). Determinant analysis of audit delay: Empirical assessment at the Jakarta Stock Exchange, Research Bulletin 09. Available @: http://www.idx.co.id/.

Warrad, L. H. (2018). The extent to which the corporate governance characteristics has affected the audit report lag in Jordanian banks. International Journal of Business and Management, 13(12), 81-92.

$\mathrm{Wu}, \mathrm{C} . \mathrm{-H} ., \mathrm{Wu}, \mathrm{C} .$, \& Liu, V. W. (2008). The release timing of annual reports and board characteristics. The international Journal of Business of Finance Research, 2(1), 22-29.

Zaitul, Z. A. (2010). Board of directors, audit, committee, auditor characteristics and timeliness of reporting in listed companies in Indonesia. Thesis University Utara Malaysia.

Zou, S., \& Stan, S. (1998). The determinants of export performance: a review of the empirical literature between 1987 and 1997. Journal of Marketing Review, 15(5), 333-356.

Appendix A

Table 1

DATA FOR THE STUDY

\begin{tabular}{|l|c|c|c|c|c|c|c|c|}
\hline Company & id & Year & ARDLY & \multicolumn{1}{|c|}{ ARDLY } & BRDSZE & FLVRG & FSZE & FSZE \\
\hline CONSOLIDATED H/MARK INS. PLC & 1 & 2008 & 213 & 2.32838 & 10 & 0.268161 & 5176617.00 & 6.71 \\
\hline CONSOLIDATED H/MARK INS. PLC & 1 & 2009 & 214 & 2.33041 & 10 & 0.25635 & 4991818.00 & 6.70 \\
\hline CONSOLIDATED H/MARK INS. PLC & 1 & 2010 & 177 & 2.24797 & 10 & 0.305089 & 5475580.00 & 6.74 \\
\hline CONSOLIDATED H/MARK INS. PLC & 1 & 2011 & 136 & 2.13354 & 9 & 0.32393 & 5685604.00 & 6.75 \\
\hline CONSOLIDATED H/MARK INS. PLC & 1 & 2012 & 184 & 2.26482 & 9 & 0.59501 & 6677772.00 & 6.82 \\
\hline CONSOLIDATED H/MARK INS. PLC & 1 & 2013 & 278 & 2.44404 & 9 & 0.690063 & 6172349.98 & 6.79 \\
\hline CONSOLIDATED H/MARK INS. PLC & 1 & 2014 & 190 & 2.27875 & 8 & 0.597639 & 6138626.00 & 6.79 \\
\hline CONSOLIDATED H/MARK INS. PLC & 1 & 2015 & 103 & 2.01284 & 15 & 0.645648 & 7023316.04 & 6.85 \\
\hline CONSOLIDATED H/MARK INS. PLC & 1 & 2016 & 103 & 2.01284 & 17 & 0.690393 & 7442464.37 & 6.87 \\
\hline CONSOLIDATED H/MARK INS. PLC & 1 & 2017 & 100 & 2 & 11 & 1.02392 & 9490174.39 & 6.98 \\
\hline GUINEA INSURANCE PLC & 2 & 2008 & 276 & 2.44091 & 9 & 0.860898 & 974621.00 & 5.99 \\
\hline GUINEA INSURANCE PLC & 2 & 2009 & 136 & 2.13354 & 8 & 0.94876 & 1324642.00 & 6.12 \\
\hline GUINEA INSURANCE PLC & 2 & 2010 & 246 & 2.39094 & 10 & 0.302299 & 4090759.00 & 6.61 \\
\hline GUINEA INSURANCE PLC & 2 & 2011 & 309 & 2.48996 & 9 & 0.436578 & 3803653.00 & 6.58 \\
\hline
\end{tabular}




\begin{tabular}{|c|c|c|c|c|c|c|c|c|}
\hline Company & id & Year & ARDLY & ARDLY & BRDSZE & FLVRG & FSZE & FSZE \\
\hline GUINEA INSURANCE PLC & 2 & 2012 & 628 & 2.79796 & 10 & 0.54494 & 3958154.00 & 6.60 \\
\hline GUINEA INSURANCE PLC & 2 & 2013 & 140 & 2.14613 & 10 & 0.41268 & 4213959.00 & 6.62 \\
\hline GUINEA INSURANCE PLC & 2 & 2014 & 309 & 2.48996 & 10 & 0.575985 & 4564728.00 & 6.66 \\
\hline GUINEA INSURANCE PLC & 2 & 2015 & 205 & 2.31175 & 15 & 0.419369 & 4116.00 & 3.61 \\
\hline GUINEA INSURANCE PLC & 2 & 2016 & 75 & 1.87506 & 16 & 0.387381 & 4103485.00 & 6.61 \\
\hline GUINEA INSURANCE PLC & 2 & 2017 & 75 & 1.87506 & 13 & 0.292652 & 4402946.00 & 6.64 \\
\hline INTE'NAL ENERGY INS CO. PLC & 3 & 2008 & 217 & 2.33646 & 9 & 0.431149 & 17596908.00 & 7.25 \\
\hline INTE'NAL ENERGY INS CO. PLC & 3 & 2009 & 169 & 2.22789 & 8 & 0.557999 & 15925401.00 & 7.20 \\
\hline INTE'NAL ENERGY INS CO. PLC & 3 & 2010 & 314 & 2.49693 & 8 & 0.597654 & 16107322.00 & 7.21 \\
\hline INTE'NAL ENERGY INS CO. PLC & 3 & 2011 & 462 & 2.66464 & 8 & 2.152497 & 11721017.00 & 7.07 \\
\hline INTE'NAL ENERGY INS CO. PLC & 3 & 2012 & 349 & 2.54283 & 10 & 1968.213 & 11137181.00 & 7.05 \\
\hline INTE'NAL ENERGY INS CO. PLC & 3 & 2013 & 458 & 2.66087 & 9 & 25.31924 & 10142274.00 & 7.01 \\
\hline INTE'NAL ENERGY INS CO. PLC & 3 & 2014 & 472 & 2.67394 & 12 & -6.73754 & 8735757.00 & 6.94 \\
\hline INTE'NAL ENERGY INS CO. PLC & 3 & 2015 & 167 & 2.22272 & 12 & -4.80552 & 8071742.00 & 6.91 \\
\hline INTE'NAL ENERGY INS CO. PLC & 3 & 2016 & 466 & 2.66839 & 12 & -2.58531 & 8957292.00 & 6.95 \\
\hline INTE'NAL ENERGY INS CO. PLC & 3 & 2017 & 398 & 2.59988 & 12 & -2.28971 & 8494013.00 & 6.93 \\
\hline INV \& ALLIED ASS. PLC & 4 & 2008 & 311 & 2.49276 & 11 & 0.639717 & 8183518.15 & 6.91 \\
\hline INV \& ALLIED ASS. PLC & 4 & 2009 & 303 & 2.48144 & 11 & 0.530726 & 8464552.00 & 6.93 \\
\hline INV \& ALLIED ASS. PLC & 4 & 2010 & 309 & 2.48996 & 7 & 0.578513 & 8088732.00 & 6.91 \\
\hline INV \& ALLIED ASS. PLC & 4 & 2011 & 323 & 2.5092 & 7 & 0.575715 & 7930388.00 & 6.90 \\
\hline INV \& ALLIED ASS. PLC & 4 & 2012 & 309 & 2.48996 & 8 & 0.361328 & 8959111.00 & 6.95 \\
\hline INV \& ALLIED ASS. PLC & 4 & 2013 & 305 & 2.4843 & 8 & 1.599142 & 9689897.00 & 6.99 \\
\hline INV \& ALLIED ASS. PLC & 4 & 2014 & 155 & 2.19033 & 8 & 1.477153 & 9503341.00 & 6.98 \\
\hline INV \& ALLIED ASS. PLC & 4 & 2015 & 136 & 2.13354 & 9 & 1.049927 & 11845987.00 & 7.07 \\
\hline INV \& ALLIED ASS. PLC & 4 & 2016 & 111 & 2.04532 & 12 & 1.614649 & 10269880.00 & 7.01 \\
\hline INV \& ALLIED ASS. PLC & 4 & 2017 & 53 & 1.72428 & 11 & 1.742965 & 11347092.00 & 7.05 \\
\hline LAW UNION \& ROCK INS. PLC & 5 & 2008 & 235 & 2.37107 & 9 & 0.50815 & 5500167.00 & 6.74 \\
\hline LAW UNION \& ROCK INS. PLC & 5 & 2009 & 262 & 2.4183 & 9 & 0.431068 & 6493932.00 & 6.81 \\
\hline LAW UNION \& ROCK INS. PLC & 5 & 2010 & 165 & 2.21748 & 11 & 0.545934 & 7367038.00 & 6.87 \\
\hline LAW UNION \& ROCK INS. PLC & 5 & 2011 & 234 & 2.36922 & 10 & 0.497751 & 7192478.00 & 6.86 \\
\hline LAW UNION \& ROCK INS. PLC & 5 & 2012 & 308 & 2.48855 & 8 & 0.878631 & 6617479.00 & 6.82 \\
\hline LAW UNION \& ROCK INS. PLC & 5 & 2013 & 180 & 2.25527 & 9 & 0.655835 & 6908473.00 & 6.84 \\
\hline LAW UNION \& ROCK INS. PLC & 5 & 2014 & 87 & 1.93952 & 12 & 0.898218 & 7293571.00 & 6.86 \\
\hline LAW UNION \& ROCK INS. PLC & 5 & 2015 & 148 & 2.17026 & 9 & 0.855582 & 8273420.00 & 6.92 \\
\hline LAW UNION \& ROCK INS. PLC & 5 & 2016 & 81 & 1.90849 & 10 & 0.702646 & 8580876.00 & 6.93 \\
\hline LAW UNION \& ROCK INS. PLC & 5 & 2017 & 43 & 1.63347 & 11 & 0.551651 & 10031774.00 & 7.00 \\
\hline LINKAGE ASSURANCE PLC & 6 & 2008 & 301 & 2.47857 & 12 & 0.62141 & 5265651.00 & 6.72 \\
\hline LINKAGE ASSURANCE PLC & 6 & 2009 & 289 & 2.4609 & 12 & 0.623161 & 4992792.00 & 6.70 \\
\hline LINKAGE ASSURANCE PLC & 6 & 2010 & 274 & 2.43775 & 12 & 0.593411 & 4801797.00 & 6.68 \\
\hline LINKAGE ASSURANCE PLC & 6 & 2011 & 260 & 2.41497 & 11 & 0.615601 & 5144951.00 & 6.71 \\
\hline LINKAGE ASSURANCE PLC & 6 & 2012 & 370 & 2.5682 & 12 & 0.358109 & 16956973.00 & 7.23 \\
\hline LINKAGE ASSURANCE PLC & 6 & 2013 & 105 & 2.02119 & 12 & 0.154252 & 17738500.00 & 7.25 \\
\hline LINKAGE ASSURANCE PLC & 6 & 2014 & 187 & 2.27184 & 13 & 0.153232 & 17976222.00 & 7.25 \\
\hline
\end{tabular}




\begin{tabular}{|c|c|c|c|c|c|c|c|c|}
\hline Company & id & Year & ARDLY & ARDLY & BRDSZE & FLVRG & FSZE & FSZE \\
\hline LINKAGE ASSURANCE PLC & 6 & 2015 & 369 & 2.56703 & 12 & 0.195154 & 19492236.00 & 7.29 \\
\hline LINKAGE ASSURANCE PLC & 6 & 2016 & 306 & 2.48572 & 12 & 0.229788 & 20332447.00 & 7.31 \\
\hline LINKAGE ASSURANCE PLC & 6 & 2017 & 203 & 2.3075 & 15 & 0.168163 & 23308158.00 & 7.37 \\
\hline MUTUAL BENEFITS ASSU. PLC & 7 & 2008 & 117 & 2.06819 & 15 & 0.402641 & 9928188.00 & 7.00 \\
\hline MUTUAL BENEFITS ASSU. PLC & 7 & 2009 & 201 & 2.3032 & 14 & 1.658508 & 11994006.00 & 7.08 \\
\hline MUTUAL BENEFITS ASSU. PLC & 7 & 2010 & 226 & 2.35411 & 15 & 1.848439 & 15139974.00 & 7.18 \\
\hline MUTUAL BENEFITS ASSU. PLC & 7 & 2011 & 314 & 2.49693 & 17 & 2.215919 & 22270736.00 & 7.35 \\
\hline MUTUAL BENEFITS ASSU. PLC & 7 & 2012 & 353 & 2.54777 & 13 & 15.1072 & 26377498.00 & 7.42 \\
\hline MUTUAL BENEFITS ASSU. PLC & 7 & 2013 & 310 & 2.49136 & 15 & 13.94125 & 32245721.00 & 7.51 \\
\hline MUTUAL BENEFITS ASSU. PLC & 7 & 2014 & 179 & 2.25285 & 15 & 5.819149 & 42390704.00 & 7.63 \\
\hline MUTUAL BENEFITS ASSU. PLC & 7 & 2015 & 236 & 2.37291 & 15 & 4.678717 & 46094942.00 & 7.66 \\
\hline MUTUAL BENEFITS ASSU. PLC & 7 & 2016 & 172 & 2.23553 & 15 & 6.452606 & 51465813.00 & 7.71 \\
\hline MUTUAL BENEFITS ASSU. PLC & 7 & 2017 & 135 & 2.13033 & 13 & 6.098401 & 57691606.00 & 7.76 \\
\hline NEM INSURANCE PLC & 8 & 2008 & 252 & 2.4014 & 7 & 0.23782 & 4997941.00 & 6.70 \\
\hline NEM INSURANCE PLC & 8 & 2009 & 268 & 2.42813 & 7 & 0.18368 & 5558149.00 & 6.74 \\
\hline NEM INSURANCE PLC & 8 & 2010 & 212 & 2.32634 & 8 & 0.244191 & 7031641.00 & 6.85 \\
\hline NEM INSURANCE PLC & 8 & 2011 & 86 & 1.9345 & 6 & 0.243998 & 8327136.00 & 6.92 \\
\hline NEM INSURANCE PLC & 8 & 2012 & 165 & 2.21748 & 6 & 0.815802 & 7809120.00 & 6.89 \\
\hline NEM INSURANCE PLC & 8 & 2013 & 304 & 2.48287 & 6 & 1.139381 & 10045877.00 & 7.00 \\
\hline NEM INSURANCE PLC & 8 & 2014 & 183 & 2.26245 & 7 & 0.90923 & 11199118.00 & 7.05 \\
\hline NEM INSURANCE PLC & 8 & 2015 & 101 & 2.00432 & 7 & 1.013806 & 12484310.00 & 7.10 \\
\hline NEM INSURANCE PLC & 8 & 2016 & 187 & 2.27184 & 11 & 0.95813 & 14492410.00 & 7.16 \\
\hline NEM INSURANCE PLC & 8 & 2017 & 51 & 1.70757 & 8 & 0.803738 & 17564096.00 & 7.24 \\
\hline PRESTIGE ASSU. CO. PLC & 9 & 2008 & 148 & 2.17026 & 10 & 0.360632 & 5945449.00 & 6.77 \\
\hline PRESTIGE ASSU. CO. PLC & 9 & 2009 & 167 & 2.22272 & 10 & 1.59724 & 6937937.00 & 6.84 \\
\hline PRESTIGE ASSU. CO. PLC & 9 & 2010 & 163 & 2.21219 & 9 & 0.588364 & 7553707.00 & 6.88 \\
\hline PRESTIGE ASSU. CO. PLC & 9 & 2011 & 114 & 2.0569 & 12 & 0.458807 & 7014720.00 & 6.85 \\
\hline PRESTIGE ASSU. CO. PLC & 9 & 2012 & 319 & 2.50379 & 10 & 1.50842 & 9698035.00 & 6.99 \\
\hline PRESTIGE ASSU. CO. PLC & 9 & 2013 & 232 & 2.36549 & 10 & 1.29633 & 10134493.00 & 7.01 \\
\hline PRESTIGE ASSU. CO. PLC & 9 & 2014 & 143 & 2.15534 & 10 & 1.599118 & 11893946.00 & 7.08 \\
\hline PRESTIGE ASSU. CO. PLC & 9 & 2015 & 55 & 1.74036 & 7 & 0.730314 & 10367741.00 & 7.02 \\
\hline PRESTIGE ASSU. CO. PLC & 9 & 2016 & 190 & 2.27875 & 7 & 0.555745 & 9689587.00 & 6.99 \\
\hline PRESTIGE ASSU. CO. PLC & 9 & 2017 & 130 & 2.11394 & 8 & 0.568375 & 11775553.00 & 7.07 \\
\hline REGENCY ALLIANCE INS. PLC & 10 & 2008 & 139 & 2.14301 & 9 & 0.096967 & 4822964.00 & 6.68 \\
\hline REGENCY ALLIANCE INS. PLC & 10 & 2009 & 226 & 2.35411 & 10 & 0.098297 & 4657569.00 & 6.67 \\
\hline REGENCY ALLIANCE INS. PLC & 10 & 2010 & 163 & 2.21219 & 10 & 0.104154 & 5158005.00 & 6.71 \\
\hline REGENCY ALLIANCE INS. PLC & 10 & 2011 & 150 & 2.17609 & 10 & 1.008822 & 5829370.00 & 6.77 \\
\hline REGENCY ALLIANCE INS. PLC & 10 & 2012 & 300 & 2.47712 & 10 & 0.511508 & 5403886.00 & 6.73 \\
\hline REGENCY ALLIANCE INS. PLC & 10 & 2013 & 166 & 2.22011 & 9 & 0.571167 & 6205026.00 & 6.79 \\
\hline REGENCY ALLIANCE INS. PLC & 10 & 2014 & 162 & 2.20952 & 9 & 0.582863 & 6833398.00 & 6.83 \\
\hline REGENCY ALLIANCE INS. PLC & 10 & 2015 & 71 & 1.85126 & 8 & 0.586006 & 7291144.00 & 6.86 \\
\hline REGENCY ALLIANCE INS. PLC & 10 & 2016 & 95 & 1.97772 & 9 & 0.580759 & 8466800.00 & 6.93 \\
\hline REGENCY ALLIANCE INS. PLC & 10 & 2017 & 102 & 2.0086 & 8 & 0.684461 & 9309327.00 & 6.97 \\
\hline
\end{tabular}




\begin{tabular}{|c|c|c|c|c|c|c|c|c|}
\hline Company & id & Year & ARDLY & ARDLY & BRDSZE & FLVRG & FSZE & FSZE \\
\hline SOVERIGN TRUST INS. PLC & 11 & 2008 & 175 & 2.24304 & 11 & 0.153775 & 5357553.34 & 6.73 \\
\hline SOVERIGN TRUST INS. PLC & 11 & 2009 & 260 & 2.41497 & 11 & 1.531651 & 5268703.00 & 6.72 \\
\hline SOVERIGN TRUST INS. PLC & 11 & 2010 & 198 & 2.29667 & 11 & 0.508527 & 5654939.00 & 6.75 \\
\hline SOVERIGN TRUST INS. PLC & 11 & 2011 & 138 & 2.13988 & 9 & 0.424847 & 7310390.00 & 6.86 \\
\hline SOVERIGN TRUST INS. PLC & 11 & 2012 & 288 & 2.45939 & 9 & -0.35044 & 7113234.00 & 6.85 \\
\hline SOVERIGN TRUST INS. PLC & 11 & 2013 & 256 & 2.40824 & 10 & 1.482935 & 8649295.00 & 6.94 \\
\hline SOVERIGN TRUST INS. PLC & 11 & 2014 & 220 & 2.34242 & 10 & 1.155022 & 8492846.00 & 6.93 \\
\hline SOVERIGN TRUST INS. PLC & 11 & 2015 & 193 & 2.28556 & 13 & 0.843684 & 9264870.00 & 6.97 \\
\hline SOVERIGN TRUST INS. PLC & 11 & 2016 & 221 & 2.34439 & 12 & 0.816768 & 9511560.00 & 6.98 \\
\hline SOVERIGN TRUST INS. PLC & 11 & 2017 & 243 & 2.38561 & 8 & 0.976949 & 10817675.00 & 7.03 \\
\hline STACO INSURANCE PLC & 12 & 2008 & 182 & 2.26007 & 8 & 0.359002 & 7205432.00 & 6.86 \\
\hline STACO INSURANCE PLC & 12 & 2009 & 284 & 2.45332 & 8 & 0.674064 & 7823701.00 & 6.89 \\
\hline STACO INSURANCE PLC & 12 & 2010 & 220 & 2.34242 & 9 & 0.830509 & 8633655.00 & 6.94 \\
\hline STACO INSURANCE PLC & 12 & 2011 & 349 & 2.54283 & 9 & 0.971658 & 8007910.00 & 6.90 \\
\hline STACO INSURANCE PLC & 12 & 2012 & 373 & 2.57171 & 9 & 2.294667 & 7912443.00 & 6.90 \\
\hline STACO INSURANCE PLC & 12 & 2013 & 306 & 2.48572 & 9 & 1.776249 & 8520839.00 & 6.93 \\
\hline STACO INSURANCE PLC & 12 & 2014 & 179 & 2.25285 & 8 & 2.003061 & 73059.00 & 4.86 \\
\hline STACO INSURANCE PLC & 12 & 2015 & 89 & 1.94939 & 8 & 2.15416 & 10939826.00 & 7.04 \\
\hline STACO INSURANCE PLC & 12 & 2016 & 184 & 2.26482 & 13 & 1.843987 & 10758297.00 & 7.03 \\
\hline STACO INSURANCE PLC & 12 & 2017 & 172 & 2.23553 & 13 & 1.76228 & 10774275.00 & 7.03 \\
\hline SUNU ASSURANCE PLC & 13 & 2008 & 199 & 2.29885 & 9 & 0.09061 & 8895093.00 & 6.95 \\
\hline SUNU ASSURANCE PLC & 13 & 2009 & 203 & 2.3075 & 9 & 0.098021 & 8994749.00 & 6.95 \\
\hline SUNU ASSURANCE PLC & 13 & 2010 & 205 & 2.31175 & 9 & 0.106266 & 8878528.00 & 6.95 \\
\hline SUNU ASSURANCE PLC & 13 & 2011 & 150 & 2.17609 & 11 & 0.122183 & 9443689.00 & 6.98 \\
\hline SUNU ASSURANCE PLC & 13 & 2012 & 270 & 2.43136 & 10 & 0.14987 & 10841642.00 & 7.04 \\
\hline SUNU ASSURANCE PLC & 13 & 2013 & 712 & 2.85248 & 16 & 0.16265 & 10842673.00 & 7.04 \\
\hline SUNU ASSURANCE PLC & 13 & 2014 & 531 & 2.72509 & 16 & 0.136448 & 10870886.00 & 7.04 \\
\hline SUNU ASSURANCE PLC & 13 & 2015 & 171 & 2.233 & 8 & 0.179046 & 11428295.00 & 7.06 \\
\hline SUNU ASSURANCE PLC & 13 & 2016 & 94 & 1.97313 & 16 & 0.147088 & 12419431.00 & 7.09 \\
\hline SUNU ASSURANCE PLC & 13 & 2017 & 243 & 2.38561 & 16 & 0.298342 & 11334642.00 & 7.05 \\
\hline UNIVERSAL INS. CO. PLC & 14 & 2008 & 250 & 2.39794 & 10 & 0.037475 & 10208822.00 & 7.01 \\
\hline UNIVERSAL INS. CO. PLC & 14 & 2009 & 511 & 2.70842 & 10 & 0.090085 & 9263130.00 & 6.97 \\
\hline UNIVERSAL INS. CO. PLC & 14 & 2010 & 418 & 2.62118 & 8 & 0.079453 & 8991074.00 & 6.95 \\
\hline UNIVERSAL INS. CO. PLC & 14 & 2011 & 767 & 2.8848 & 8 & 0.251567 & 10364491.00 & 7.02 \\
\hline UNIVERSAL INS. CO. PLC & 14 & 2012 & 407 & 2.60959 & 13 & 0.266279 & 13026641.00 & 7.11 \\
\hline UNIVERSAL INS. CO. PLC & 14 & 2013 & 485 & 2.68574 & 8 & 0.277858 & 13335229.00 & 7.13 \\
\hline UNIVERSAL INS. CO. PLC & 14 & 2014 & 572 & 2.7574 & 8 & 0.258279 & 13508866.00 & 7.13 \\
\hline UNIVERSAL INS. CO. PLC & 14 & 2015 & 523 & 2.7185 & 8 & 0.27317 & 13618472.00 & 7.13 \\
\hline UNIVERSAL INS. CO. PLC & 14 & 2016 & 328 & 2.51587 & 8 & 0.298488 & 13819274.00 & 7.14 \\
\hline UNIVERSAL INS. CO. PLC & 14 & 2017 & 206 & 2.31387 & 8 & 0.326767 & 13815316.00 & 7.14 \\
\hline WAPIC (INTERCONTINAL INS. PLC & 15 & 2008 & 219 & 2.34044 & 9 & 0.492949 & 12937763.00 & 7.11 \\
\hline WAPIC (INTERCONTINAL INS. PLC & 15 & 2009 & 295 & 2.46982 & 9 & 0.538949 & 12377455.00 & 7.09 \\
\hline WAPIC (INTERCONTINAL INS. PLC & 15 & 2010 & 276 & 2.44091 & 9 & 0.532868 & 11467564.00 & 7.06 \\
\hline
\end{tabular}




\begin{tabular}{|l|c|c|c|c|c|c|c|c|}
\hline Company & id & Year & ARDLY & ARDLY & BRDSZE & FLVRG & FSZE & FSZE \\
\hline WAPIC (INTERCONTINAL INS. PLC & 15 & 2011 & 108 & 2.03342 & 10 & 0.530563 & 12008216.00 & 7.08 \\
\hline WAPIC (INTERCONTINAL INS. PLC & 15 & 2012 & 210 & 2.32222 & 14 & 0.66312 & 12678755.00 & 7.10 \\
\hline WAPIC (INTERCONTINAL INS. PLC & 15 & 2013 & 181 & 2.25768 & 17 & 0.572975 & 22304046.00 & 7.35 \\
\hline WAPIC (INTERCONTINAL INS. PLC & 15 & 2014 & 91 & 1.95904 & 14 & 0.553374 & 22058871.00 & 7.34 \\
\hline WAPIC (INTERCONTINAL INS. PLC & 15 & 2015 & 71 & 1.85126 & 11 & 0.583621 & 23694610.00 & 7.37 \\
\hline WAPIC (INTERCONTINAL INS. PLC & 15 & 2016 & 107 & 2.02938 & 9 & 0.563535 & 25902052.00 & 7.41 \\
\hline WAPIC (INTERCONTINAL INS. PLC & 15 & 2017 & 124 & 2.09342 & 11 & 0.592877 & 28604611.00 & 7.46 \\
\hline
\end{tabular}

Source: Annual Reports and Accounts of the sampled companies 2008-2017 